\title{
Cross-species analyses of the cortical GABAergic and subplate neural populations
}

\author{
Barbara Clancy ${ }^{1,2 *}$, Terri J. Teague-Ross ${ }^{1}$ and Radhakrishnan Nagarajan ${ }^{3}$ \\ 1 Department of Biology, University of Central Arkansas, Conway, AR, USA \\ 2 Department of Neurobiology and Developmental Sciences, University of Arkansas for Medical Sciences, Little Rock, AR, USA \\ ${ }^{3}$ Department of Biostatistics, University of Arkansas for Medical Sciences, Little Rock, AR, USA
}

\section{Edited by:}

Kathleen S. Rockland, RIKEN Brain

Science Institute, Japan

\section{Reviewed by:}

Roger Reep, University of Florida, USA

Nada Zecevic, University of

Connecticut Health Center, USA

\section{*Correspondence:}

Barbara Clancy, Department of Biology,

College of Natural Sciences and

Mathematics, University of Central

Arkansas, 201 Donaghey Avenue,

180 Lewis Science Center, Conway,

AR 72035, USA.

e-mail: barbaraclancy@mac.com
Cortical GABAergic ( $\gamma$-aminobutyric acidergic) neurons include a recently identified subset whose projections extend over relatively long distances in adult rodents and primates. A number of these inhibitory projection neurons are located in and above the conventionally identified white matter, suggesting their persistence from, or a correspondence with, the developmental subplate. GABAergic and subplate neurons share some unique properties unlike those of the more prevalent pyramidal neurons. To better understand the GABAergic and subplate populations, we constructed a database of neural developmental events common to the three species most frequently used in experimental studies: rat, mouse, and macaque, using data from the online database www.translatingtime.net as well as GABAergic and subplate developmental data from the empirical literature. We used a general linear model to test for similarities and differences, a valid approach because the sequence of most neurodevelopmental events is remarkably conserved across mammalian species. Similarities between the two rodent populations are striking, permitting us to identify developmental dates for GABAergic and subplate neural events in rats that were previously identified only in mice, as well as the timing in mouse development for events previously identified in rats. Primate comparative data are also compelling, although slight variability in statistical error measurement indicates differences in primate GABAergic and subplate events when compared to rodents. Although human extrapolations are challenging because fewer empirical data points are available, and because human data display more variability, we also produce estimates of dates for GABAergic and subplate neural events that have not yet been, or cannot be, determined empirically in humans.

Keywords: GABA, statistical analysis, persisting subplate neurons, layer Vlb, white matter neurons, cross-species correlations, rodent development, human development

\section{INTRODUCTION}

Cortical GABAergic ( $\gamma$-aminobutyric acidergic) neurons can be parceled into a number of subgroups based on variations in morphology, birthplaces, mature locations, colocalized peptides, and electrophysiological parameters (Hendry and Jones, 1991; Ascoli et al., 2008; Burkhalter, 2008). Despite such diversity, conventional models of cortical function include GABAergic neurons as participators only in local connectivity, such that the designation of "interneuron" is often used interchangeably with GABAergic to describe cortical neurons that play an inhibitory role. However, cortical GABAergic categories recently were extended to include a subset of phylogenetically conserved neurons that project axons across long distances - the newly identified long-range interneurons, perhaps more precisely called cortical GABAergic projection neurons (McDonald and Burkhalter, 1993; Gonchar et al., 1995; Fabri and Manzoni, 1996, 2004; Tomioka et al., 2005; Pinto et al., 2006; Higo et al., 2007; Tomioka and Rockland, 2007).

One intriguing aspect of the latest subgroup is that the majority of the long-range GABAergic projections extend from neurons located in cortical layer I, cortical white matter, and the subgriseal region of the cortex (subjacent to cortical layer VI) (Tomioka et al., 2005; Tomioka and Rockland, 2007). This prompted the suggestion that the GABAergic projection neurons might be a subset of the little-studied cells that persist in the adult brain from the developmental subplate (Tomioka et al., 2005; Tomioka and Rockland, 2007).

\section{GABAergic AND SUBPLATE NEURONS}

Early in development, the cells of the future layer I, as well as the future subplate/white matter neurons, are merged as the preplate before neurons of the developing cortical plate split the preplate into a superficial region (later called layer 1) and a subgriseal region (later called the subplate) (Marin-Padilla, 1978, 1988). The exact percentage of subplate cells that survive into adulthood is somewhat difficult to identify (Chun and Shatz, 1989a; Valverde et al., 1995; Price et al., 1997; Robertson et al., 2000), but it is well-documented that some survive an early wave of cell death to remain in the mature white matter in human and non-human primate cortex (Kostovic and Rakic, 1980; Somogyi et al., 1981; Schiffmann et al., 1988; Yan et al., 1996) and in carnivores (Chun and Shatz, 1989b). Moreover, they survive both in the white matter and as a well-defined structure subjacent to the cortex in rodents, species used for the majority of neural studies (Somogyi et al., 1984; Lauder et al., 1986; Huntley et al., 
1988; Luskin et al., 1988; Reep and Goodwin, 1988; Winer and Larue, 1989; Cobas et al., 1991; Woo et al., 1991; Woo and Finlay, 1996; Reep, 2000).

As depicted in Figure 1, even in rodents the persisting subplate cells that remain in a distinct layer are essentially positioned in the white matter. They sit above the conventionally-identified white matter, but below a stria of intracortical connections (Reep and Goodwin, 1988; Clancy and Cauller, 1999; Reep, 2000; TeagueRoss et al., 2008), making them more comparable to the persisting white matter (interstitial) population in primates and carnivores than is often acknowledged. GABAergic neurons account for $15-25 \%$ of all the neurons in the region depicted as the persisting subplate, similar to their percentage in the cortex overall (Hendry et al., 1983, 1987; Chun et al., 1987; Esclapez et al., 1987; Meinecke and Peters, 1987; Peduzzi, 1988; Del Rio et al., 2000; Tomioka et al., 2005; Burkhalter, 2008). The subplate may include a GABAergic population that survives from cells located at the intermediate zone/ subventricular zone border early in development (Del Rio et al., 2000), as well as some lower intermediate zone GABAergic cells that may later merge with subplate cells (Van Eden et al., 1989).

\section{CORRESPONDENCE BETWEEN GABAergic AND SUBPLATE NEURONS}

The location of the long distance GABAergic neurons, and the possibility that some may be surviving subplate neurons, is interesting because GABAergic and subplate neurons (both developmental and those that persist across maturity, including neurons in the white matter) have a notable relationship, and share some comparable characteristics. Similar to the sometimes confusing GABAergic nomenclature recently addressed by the Pettilla committee (Ascoli et al., 2008), surviving subplate cells have been assigned a variety of different names in mature cortex, including border neurons (Hogan and Berman, 1992), white matter neurons (Kostovic and Rakic, 1980), subgriseal neurons (Clancy and Cauller, 1999), layer VII (Clancy and Cauller, 1999; Reep, 2000), layer VIb (Gomez-Pinilla and Cotman, 1992), deep layer VI (McDonald and Burkhalter, 1993), upper subplate neurons (Marin-Padilla and Marin-Padilla, 1982), and the deep cortical band (Kristt, 1979). In this study we will use the term "persisting subplate neurons" (Reep, 2000) for those resilient cells that remain from the developmental subplate in and above the white matter across maturation, where they continue to participate in cortical function (Clancy et al., 1997, 2001b; Bayer et al., 2004; Torres-Reveron and Friedlander, 2007; Pinon et al., 2009), and apparently include the GABAergic subset that sends projections for long distances (Tomioka et al., 2005; Tomioka and Rockland, 2007).

Subplate neurons can be activated by GABA, including intrinsic GABAergic activation from other subplate neurons (Princivalle et al., 2000; Hanganu et al., 2001). The subplate is equally important in GABAergic function as it is required for a developmental change that switches GABAergic input from producing a depolarizing response to its more familiar hyperpolarizing role (Lauder et al., 1986; Kanold and Shatz, 2006).

In fact, it is difficult to comprehensively characterize one population without including the other. Both GABAergic and subplate populations have been implicated in similar disorders associated with development, including epilepsy and schizophrenia (Akbarian et al., 1995, 1996; Kirkpatrick et al., 1999; Lein et al., 1999; Kanold, 2004; Woo et al., 2004; Levitt, 2005; Lewis et al., 2005; Eastwood and Harrison, 2006; Freund and Katona, 2007; Leviton and Gressens, 2007; Lazar et al., 2008; Metin et al., 2008). Both populations may be particularly vulnerable to developmental insults, including those associated with premature birth (Nie and Wong-Riley, 1996; Ulfig, 2002; McQuillen and Ferriero, 2005), and in the white matter damage that often follows intrauterine infection (Dammann et al., 2002; Jensen et al., 2003; Kostovic and Judas, 2006; Robinson et al., 2006; Leviton and Gressens, 2007). Both populations play roles that change across development and maturity (Owens and Kriegstein, 2002; Ben-Ari et al., 2004; Kanold and Shatz, 2006; Friedlander, 2008), and it has been proposed that both populations may establish mechanisms during early development that lie dormant until triggered at later ages (Kanold et al., 2003; Butt et al., 2007).

Both GABAergic and subplate populations include numerous and diverse morphological subsets that are different from the more prevalent cortical pyramidal neurons (although each population may include cells with pyramidal morphology), and both populations contain a subset whose projections may travel long distances,

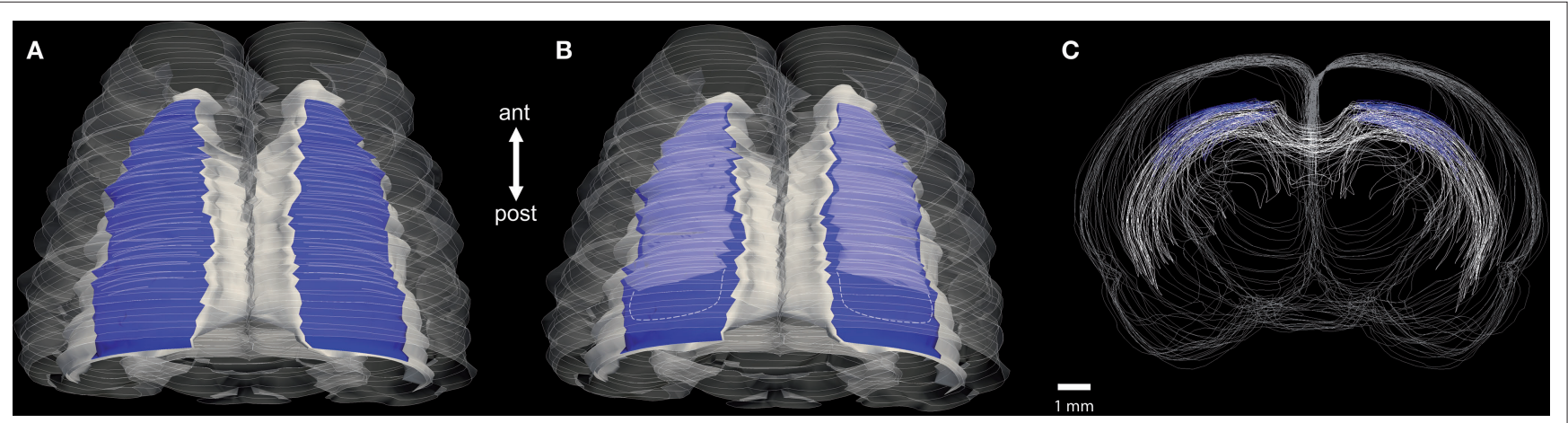

FIGURE 1 | (A) Schematic of a dorsal view of an adult rat brain produced from serial sections using Neurolucida (Version 8; MicroBrightField, Williston, VT, USA). Persisting subplate cells (blue) lie above the white matter (solid white). The brain outline is depicted in shadow. (B) The same brain with the infracortical stria, a fiber tract above the persisting subplate cells, shown in transparent white. The white, dashed line represents the continuity, but decreasing thickness, of the infracortical stria in posterior brain regions. (C) Overlapping coronal serial sections depicting the location of the persisting subplate cells (blue) with the conventional white matter outlined (white). Scale bar = approximately $1.0 \mathrm{~mm}$. Abbreviations: ant (anterior); post (posterior). 
sometimes crossing areal boundaries, as well as a subset that focuses projections on cortical layer I (Cauller et al., 1998; Clancy and Cauller, 1999; Tomioka et al., 2005; Silberberg and Markram, 2007; Tomioka and Rockland, 2007). Both populations are similarly heterogeneous in their electrophysiological properties (Friauf et al., 1990; Luhmann et al., 2000; Hanganu et al., 2001; Voigt et al., 2001; Miyoshi et al., 2004, 2007; Torres-Reveron and Friedlander, 2007), and in the numerous signaling chemicals they sequester (Chun and Shatz, 1989a,b; Bredt and Snyder, 1992; Gao et al., 1999; Tao et al., 1999; Robertson et al., 2000; Clancy et al., 2001b; Heuer et al., 2003; Bayer et al., 2004; Garbossa et al., 2004; Tomioka et al., 2005; Tomioka and Rockland, 2007; Burkhalter, 2008). Moreover, subsets of both populations may share a common non-cortical birthplace in the ganglionic eminences (Tamamaki et al., 1997; Lavdas et al., 1999; Anderson et al., 2001; McQuillen and Ferriero, 2005), raising the possibility that some may descend from similar sets of precursors. Supporting this notion, both populations use somewhat similar molecular modes of migration, different from the mechanism used by pyramidal cells (Gilmore and Herrup, 2001).

\section{SPARSE CONNECTIVITY CAN HAVE POWERFUL EFFECTS}

Although the contribution of the GABAergic interneurons to cortical function is undisputed, and the critical role of the subplate in cortical development is well-accepted (McConnell et al., 1989; Ghosh et al., 1990; De Carlos and O'Leary, 1992), conventional models of mature cognitive function do not yet incorporate contributions of either the projection GABAergic or the persisting subplate neurons. When numbers are reduced compared to other neural populations, there may be a tendency to simply dismiss those that persist as "sparse," "remnants," or "relics". Unfortunately, such terminology implies a fairly unessential function, and it seems important to avoid such categorization until additional information on their function is available. Persisting subplate cells in adult mammalian species have thus far eluded characterization as an easily observable and/or organized structure. Several studies, however, have suggested revising the whole idea of a "remnant" population, and provided evidence for the organization and participation of the persisting subplate cells in mature cortical function (Clancy et al., 2001b; Colombo and Bentham, 2006; Torres-Reveron and Friedlander, 2007; Chang et al., 2008; Friedlander, 2008; Friedlander and Torres-Reveron, 2009; Suarez-Sola et al., 2009).

With the recent indication that the long distance projection GABAergic neurons are associated with the persisting subplate population, including neurons that remain in isolated positions in both cortex and white matter, a role for the persisting subplate population is strengthened. Indeed, the mathematical principles underlying small-world networks suggest that sparse connectivity is a plausible design underlying important cognitive function. Long-range inhibition, even from relatively sparse connections, can be a potent network component (Sur and Rubenstein, 2005). In small-world networks (Watts and Strogatz, 1998) (inspired by the same mathematics behind "Six Degrees of Kevin Bacon"), clusters of cells link to their nearest neighbors, while some connect to distant clusters. This pattern can serve as the basis for a surprisingly strong communication network, especially when it is amplified by local input, as is likely the case for both the long-range GABAergic and the persisting subplate populations.

\section{SPECIES SIMILARITIES AND DIFFERENCES}

Most characteristics of GABAergic and subplate cells are conserved across species (Levitt, 2005; Wang and Kriegstein, 2009), and even some GABAergic features previously considered to be exclusive to primates, or wholly exclusive to humans, were later identified in other species (Meyer et al., 1998; Yuste, 2005; Petanjek et al., 2009). However, species differences have been reported in both populations, including in birthplace, migration, and final locations in mature cortices, suggesting that both populations may drive and/or be driven by evolutionary processes (Peduzzi, 1988; Letinic et al., 2002; Rakic, 2003, 2006; Watakabe et al., 2006; Petanjek et al., 2008; Suarez-Sola et al., 2009). In addition to the evolutionary aspects, the question of species differences has pragmatic impact because rodent models are necessary in studies for both normal (Rakic, 2006) and abnormal neural development (Goffinet and Rakic, 2000; Levitt, 2005; Robinson et al., 2005), and non-human primate and rodent studies are used routinely to fill in gaps in knowledge of human development e.g. (de Graaf-Peters and Hadders-Algra, 2006).

\section{STATISTICAL MODELING OF SPECIES SIMILARITIES AND DIFFERENCES}

In a series of previous studies, mathematical models have been used to successfully identify both similarities and relative differences in the timing of neural "events" when comparing primate and nonprimate development (http://www.translatingtime.net) (Clancy et al., 2001a, 2007a,b; Nagarajan and Clancy, 2008). For the purpose of this review, "neural events" are defined as milestones pertaining to neural development such as the post conception (PC) date that neurons destined for the various cortical layers are generated. (Complete lists are included in Table 3 at the end of this review.) Mathematical approaches are valid because despite species differences, including differences in the duration of development, the size of most brain regions scales similarly across species (Finlay and Darlington, 1995; Finlay et al., 1998, 2001). Central to this meta analysis, the timing of events that occur in most neural regions is remarkably conserved (Finlay and Darlington, 1995; Finlay et al., 1998, 2001).

Moreover, even neural regions that do display species-related duration differences can be modeled with appropriate mathematical adjustments (Clancy et al., 2000, 2001a). As a practical illustration, in a careful study of neurogenesis of the primate cortical plate (Smart et al., 2002), the authors urged caution when comparing histogenesis results between monkey and mouse, pointing out what seemed to be a disparity in that mouse PC days 11-12 compare to monkey PC days 46-65. In fact, our statistical modeling approach indicates the two time periods are remarkably comparable, predicting PC 11-12 in mice to correspond to PC 44-50 in macaques (these and other comparisons can be accessed at http://www. translatingtime.net).

\section{STATISTICAL ANALYSES INCLUDING GABAergic AND SUBPLATE EMPIRICAL DATA}

The most pragmatic application of statistical modeling is that neural events empirically derived in one species can be compared and successfully applied to another. Therefore, given the potentially important contributions of the long distance 
GABAergic and persisting subplate populations, we reasoned any additional information about these two populations, including comparative cross-species data, is likely to be useful. At this time, no empirical developmental data are yet available specifically for the cortical GABAergic projection neurons. However developmental data are available for both general populations that include them, the GABAergic and subplate populations. We assembled a database of GABAergic and subplate developmental events (e.g. the PC day subplate neurogenesis begins, the day GABAergic cells are first found in the subplate). We then applied cross species statistical modeling, and tested if species similarities and differences might be indicated by statistical analysis of the developmental sequences.

For this review we generated three sets of results: (i) We compare and translate GABAergic and subplate developmental neural events between rats and mice, since a majority of the events have been documented in the literature in these two species. (ii) In order to understand the impact of translation from rodents to primates, we present the GABAergic and subplate predictions by pooling the events from mice, rats, and macaques, as sufficient data are available in macaques to allow such conversions. More importantly for this review, we discuss the prediction of common events across these three species with and without subplate and GABAergic events. (iii) Finally, we discuss the results obtained by pooling the data for mice, rats, macaques and humans. As would be expected, the number of empirically derived events in humans is considerably lower as compared to other three species. However, the results we present indicate that it might be possible to arrive at meaningful approximations to unknown human events by "translating" empirically derived events across other species.

\section{STANDARD STATISTICAL TECHNIQUES}

Our database was gleaned from the published literature, including the timing of 20 GABAergic and subplate neural events established in two or more mammalian species. We then incorporated these dates into our previously established database of 101 neural events freely available at http://www.translatingtime.net: (i) For translation of GABAergic and subplate developmental neural events between rats and mice, we considered a total of 135 events, comprised of dates from the empirical literature for mice, rats, and both mice and rats. (ii) For translation from rodents to primates, we considered the common events for mice, rats, and macaques, with GABAergic and subplate events (46 events) and without (38 events). We restricted the analysis to the common events in order to facilitate comparison of the regression results across these three species. (iii) Finally, we discuss the results obtained by pooling data on mice, rats, macaques and humans. This portion of the analysis consisted of events empirically derived in at least one of the species (119 events total). Tables that list the specific neural events, including empirically derived dates as well as the predictions generated by our analyses, are included at the end of this review (Table 3). In our analyses, data are standardized whenever possible such that the 24 -h period following conception is designated PC 1 , and the 24-h period immediately following birth is considered postnatal (PN) day 0 . The "start" date is the day on which $5 \%$ of the neurons of a given structure are generated, and "end" is assigned similarly. If no clear "peak" is evident in the empirical neurogenesis data, a midpoint is used.

Because the timing of most developmental events in mammalian brains follows a similar pattern across species (Finlay and Darlington, 1995), standard regression techniques can be used to compare cross-species neural development (Clancy et al., 2001a, 2007a,b). The present study uses a general linear model to translate the events across the species. The response values (i.e. empirically derived event timings) were log-transformed and each of the predictors representing the species and the events were represented by dummy variables (Darlington, 1990). The model parameters were subsequently estimated using least squares regression. Confidence limits were determined in the log-scale for each of the estimated event timings (Statistical software "R" 2.8.1).

\section{RESULTS OF STATISTICAL ANALYSES}

Although we found empirical data for many developmental GABAergic and subplate data points in both rats and mice, there were a numbers of events for which we found empirical data points in only one of these important experimental species. Predictions for GABAergic and subplate events in the rodent species using the general linear model from the documented events are depicted in Table 1. The predicted values along with their confidence intervals are shown in the log-scale. The predicted values are also transformed back in the original scale (PC days) for clarity. Because so many developmental data points are available in these two species, cross-rodent conversions between these closely related species are especially compelling (Nagarajan and Clancy, 2008).

\section{COMPARISONS OF COMMON EVENTS IN RATS, MICE, AND MACAOUES WITH AND WITHOUT SUBPLATE AND GABAergic EVENTS}

There are reported species differences, most notably in rodent/ primate comparisons, in the relative timing (heterochrony) and location of neurogenesis for both the GABAergic and subplate cell populations (Letinic et al., 2002; Smart et al., 2002; Rakic, 2003, 2006). Because a mathematical modeling approach has previously permitted identification of two neural systems whose temporal milestones "shift" in primates - the limbic system (shifted to occur earlier in primates) and cortical neurogenesis events (shifted to occur later when compared to non-primates) (Clancy et al., 2000), we anticipated our model would be able to establish if similar discrepancies occur in GABAergic and subplate neural development events when comparing the timing of rodent/primate events. In order to facilitate a direct comparison between rodents and macaques, we selected the common events across these species including the GABA/subplate events (46 events) and excluding them (38 events).

As depicted in the graphs in Figure 2, the sums of absolute error (e) between the empirical values and those predicted by the general linear model are similar for mice and rats (mice $e=36.6$; rats $e=39.7)$, but much higher for macaques ( $e=235.8$ ). However, the correlation coefficient between the empirical and predicted values is significant for all three species (mice $r=0.95$; rats $r=0.96$; macaques $r=0.93 ; p<0.001$ ) indicating that a general linear model is a useful tool in cross species translations. Yet the results 
Table 1 | GABAergic and subplate developmental neural events are statistically "translated" between rats and mice.

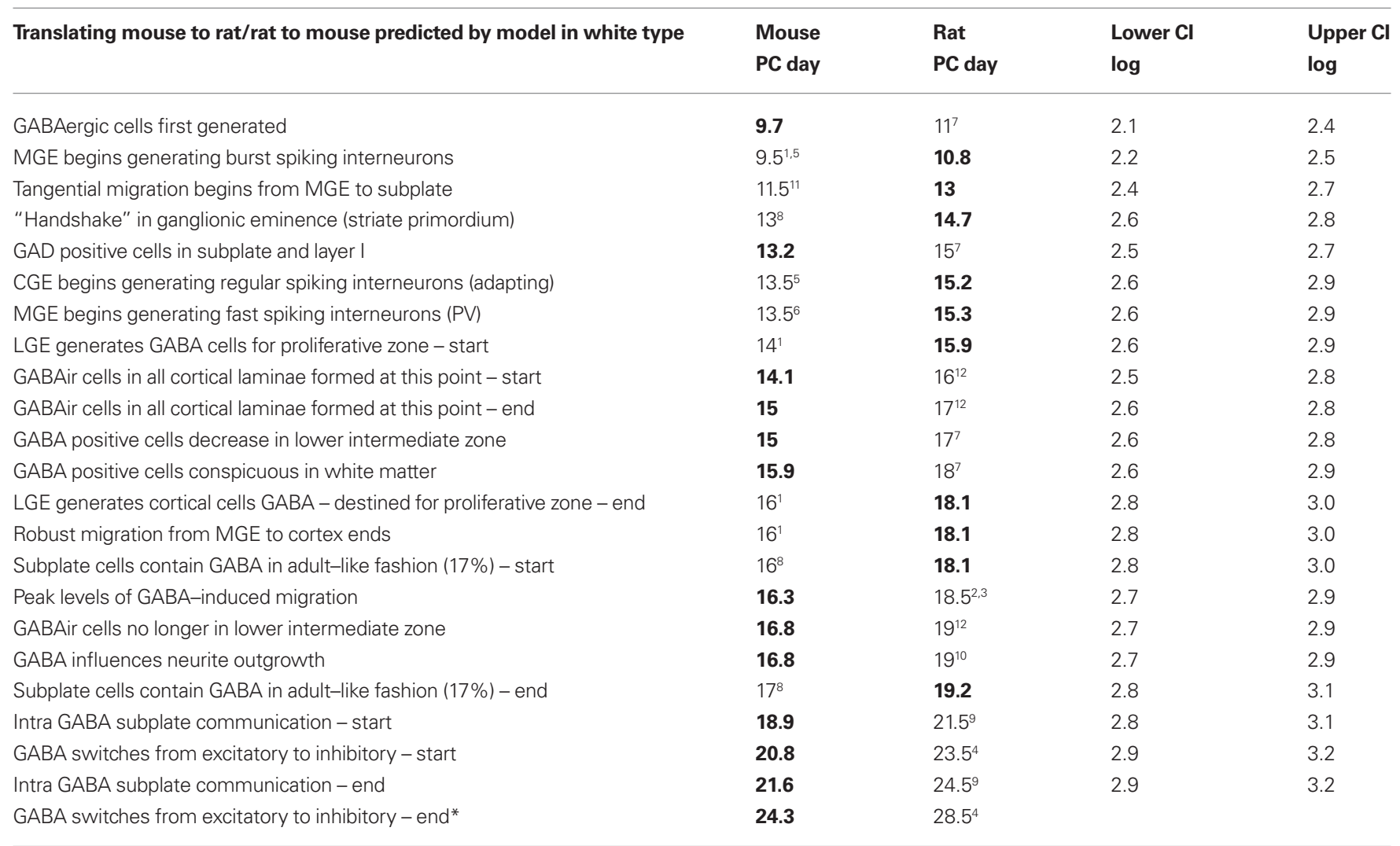

*Base event; translation generated at www.translatingtime.net.

References: 1 (Anderson et al., 2001), ${ }^{2}$ (Behar et al., 1996), ${ }^{3}$ (Behar et al., 1998), 4 (Ben-Ari et al., 1997), 5 (Butt et al., 2007), 6 (Butt et al., 2005), 7 (DeDiego et al., 1994), ${ }^{8}$ (Del Rio et al., 2000), 9 (Hanganu et al., 2002), 10 (Maric et al., 2001), "11 (Marin and Rubenstein, 2001), 12 (Van Eden et al., 1989).

Abbreviations: MGE (medial ganglionic eminence); GABA ( $\gamma$-aminobutyric acid); SOM (somatostatin); CR (calretinin); VIP (vasointestinal polypeptide); PV (parvalbumin); LGE (lateral ganglionic eminence); GAD (glutamic acid decarboxylase); GABAir ( $\gamma$-aminobutyric acid immunoreactive).

of the sum of absolute error do indicate that translation of the events from rodent to primates can be more challenging. Some of the discrepancy in the sum of squared error may be attributed to additional variability in the macaque events as opposed to those of rats and mice.

We then ran the same analysis including GABAergic and subplate events because were especially interested if the development of these two populations might exhibit any differences when compared to the other neural events, based on the reports that these two populations might have particular species-specific differences (Kostovic and Rakic, 1990; Smart et al., 2002).

In each of the three species, the correlation coefficient values ( $r$ ) do not change significantly with the inclusion of GABAergic and subplate events (Figure 3) when compared to the values generated without including these events (Figure 2). The $r$ for mice increases from 0.95 to 0.97 ; for rats it increases from 0.96 to 0.97 ; for macaques it increases from 0.93 to 0.95 ( $p=0.001$ for all). When GABAergic and subplate events are considered, once again there is considerable similarity in the sum of absolute error between the empirical and predicted values in the rodents; mice $(e=47.9 ; p=0.001)$ and rats $(e=53.5 ; p=001)$, and again error for macaques is higher $(e=312.1 ; p=001)$. However, the magnitude of the error (e) was higher across all three species when the data includes GABAergic and subplate events (Figure 3) as opposed to when they are excluded (Figure 2). For mice it increases from 36.6 to 47.9 ; for rats from 39.7 to 53.5 ; and for macaques it increases from 235.8 to 312.1 ( $p=0.001$ for all). This would appear to indicate something is indeed different in these GABAergic and subplate events when comparing rodents to primates, and it is more distinctive in primates.

These analyses are necessarily preliminary as they are based on a somewhat limited dataset, but they do support the neuroanatomical data noting slight species differences in the GABAergic and subplate populations (Peduzzi, 1988; Letinic et al., 2002; Rakic, 2003). Clearly a more detailed study with increased numbers of empirical events as they become available will be necessary in order to gain sufficient insight into the impact of GABAergic and subplate events on evolutionary modifications between rodent and primate species.

\section{POOLING MAMMALIAN DATA TO PREDICT HUMAN EVENTS}

The difficulty of establishing precise empirical dates for neural events in human development is extremely challenging, particularly due to individual variation and observational error. The 


\section{A \\ Confidence Limits}
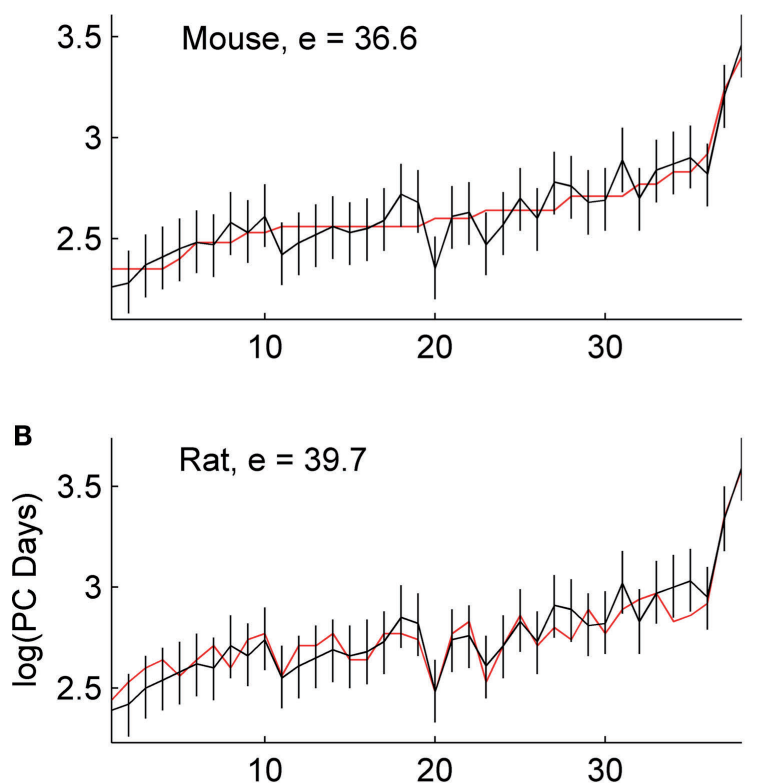

C

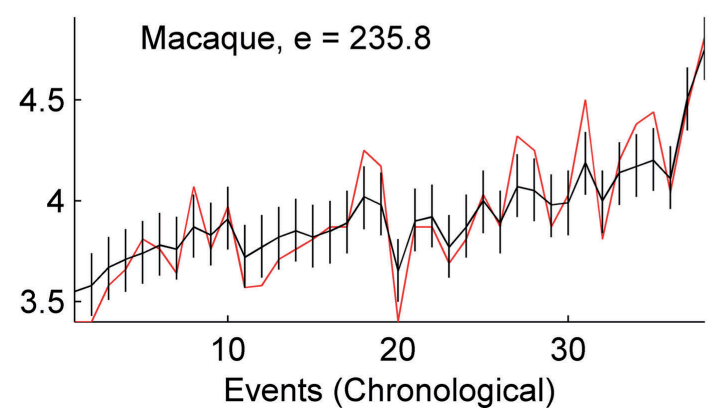

FIGURE 2 |The predicted (black) and empirical values (red) of the post-conceptional days in the log-scale, i.e. log(PC days), of the $38 \mathrm{common}$ events excluding GABAergic and subplate events across mice, rats and macaques are shown in $(A),(B)$ and $(C)$ respectively. The rat and macaque events are in the same chronological order as that of mouse events. The
D Correlation

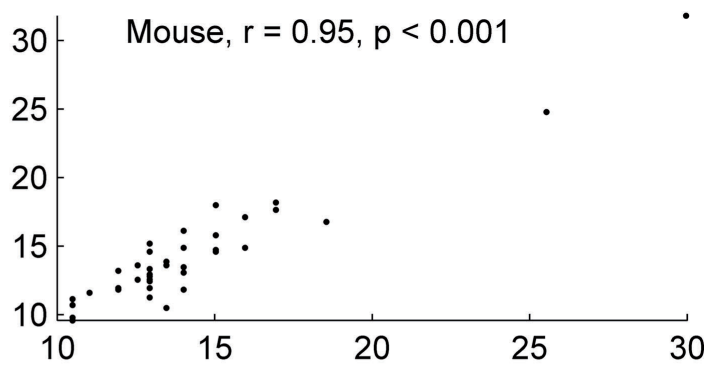

$\mathrm{E}$

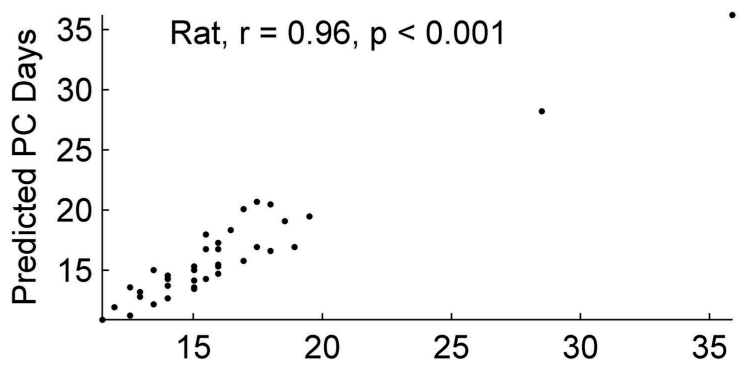

$\mathbf{F}$

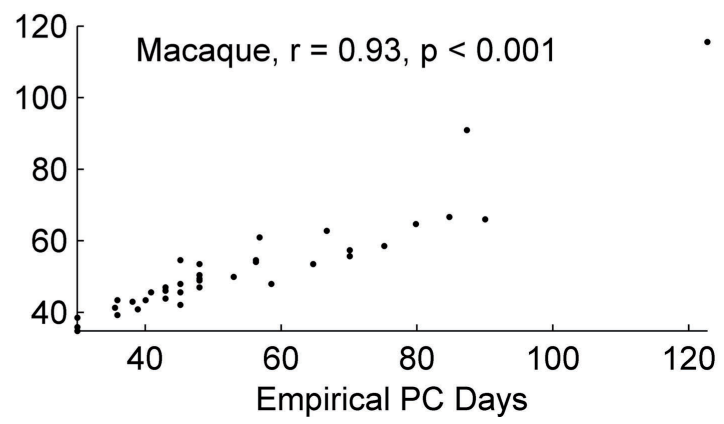

confidence limits (log-scale) about the predicted values and the sum of absolute error (e) between the empirical and the predicted values are also shown in (A), (B) and (C). The correlation coefficient ( $r$ ) between the predicted and the empirical values for mice, rats and macaques are shown in (D), (E) and (F) respectively. The names of the events are included in Table 2 at the end of this review. limitations are unavoidable: samples sizes are necessarily small, dates of conception are estimated, sampling intervals are essentially opportune, the most convincing techniques to establish dates of neurogenesis require invasive techniques, to name but a few. However, it is possible to arrive at meaningful approximation to unknown human events using statistical techniques to translating empirically derived dates from other mammalian species (Clancy et al., 2000).

Predictions for human GABAergic and subplate events translated using empirically derived statistical comparisons from our database (119 events) for at least one of the species (rat, mouse and macaque) are included in Table 2. For the predictions listed in Table 2, we used the statistical model to predict human events for data points that are not yet known, as well as for some events that are reported in the empirical literature. In most cases where empirical data are available, the model predictions were for dates earlier than those reported in the literature.
This may be an indication of variability, but we have reason to propose that our data are accurate based on a principle, well known to statisticians, called the "bootstrap effect" (Cronbach and Meehl, 1955). Since the estimates generated by any mathematical model are based on all the empirical data used to build the model, errors can be "averaged out" such that the model's estimates may even be more accurate than empirical data. This seems especially compelling for human data, where techniques are extraordinarily challenging and sampling/observation intervals are often wide, such that an event might not be documented until well after it has occurred.

We have some direct evidence of the value of the bootstrap effect from a previous study (Clancy et al., 2000) that consistently predicted a much earlier date for human eye opening than any date then found in the empirical literature. When four-dimensional sonograms were perfected, it became clear that the statistical model had been accurate (Clancy et al., 2007a). 
A Confidence Limits
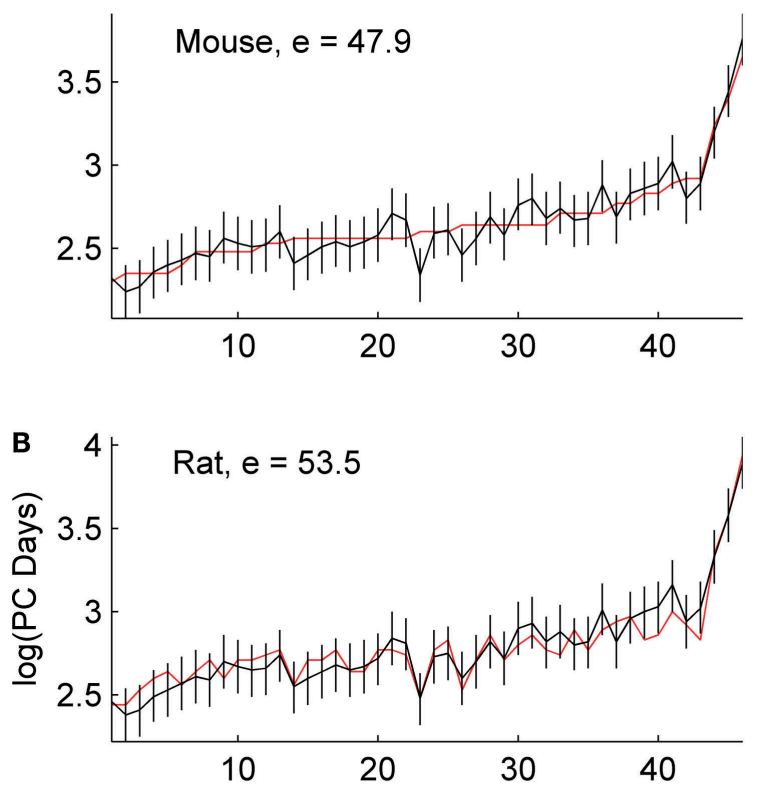

C

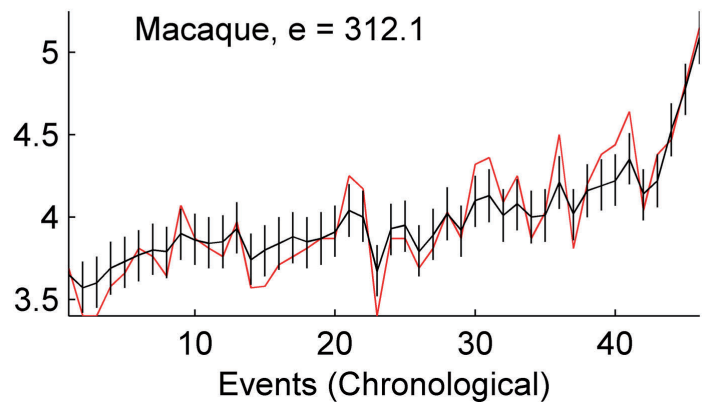

FIGURE 3 |The predicted (black) and empirical values (red) of the post-conceptional days in the log-scale, i.e. $\log (\mathrm{PC}$ days), of the 46 common events including GABAergic and subplate events across mice, rats and macaques are shown in $(A),(B)$ and $(C)$ respectively. The rat and macaque events are in the same chronological order as the mouse events. The
D Correlation
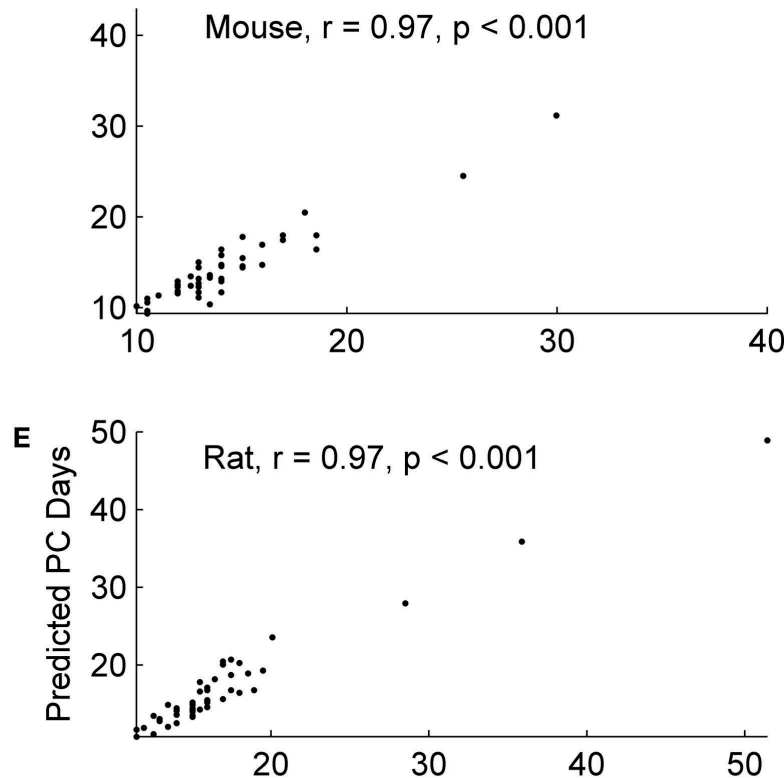

$\mathbf{F}$

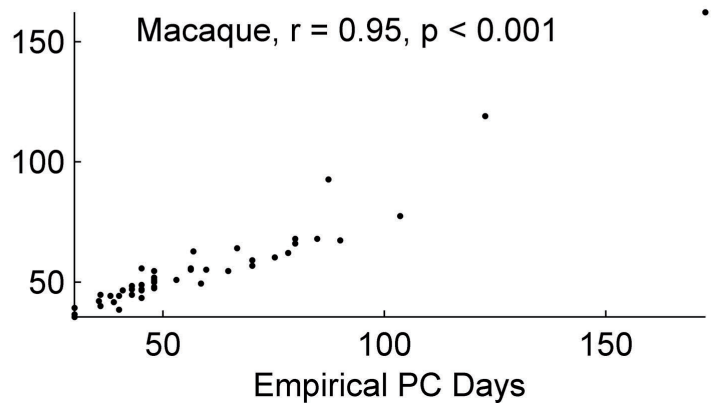

confidence limits (log-scale) for the predicted values and the sum of absolute error (e) between the empirical and the predicted values are also shown in (A) (B) and (C). The correlation coefficient ( $\boldsymbol{r})$ between the predicted and the empirical values for mice, rats and macaques are shown in (D), (E) and (F) respectively. The specific events are included in Table 3 at the end of this review.

\section{VALUE AND LIMITATIONS OF CROSS SPECIES TRANSLATIONS}

The pragamatic value of the cross species translations in direct savings of time and resources when intervals for studies might be narrowed is a compelling reason to add this type of analysis to the growing array of modern neuroanatomical tools. In some case, it might eliminate the necessity of repeating a study already accomplished in one species (as our data suggest is possible when translating from mice to rats, or rats to mice), or at the least contribute to a narrowing of time intervals (as our data suggest is possible for humans). And although correlations between data available in the empirical literature and data produced by the model were already significant, we expect future predictions will become more accurate as additional data points are added to our database.

On the other hand, we certainly do not suggest that there are no differences in the brain development of diverse mammalian species. Mathematical modeling can successfully adjust for some rodent/ primate differences (Clancy et al., 2001a), such that comparisons and predictions are not overly distorted by differences in brain sizes, or what might seem to be a relatively prolonged time window for neurogenesis in primates when compared to rats. Yet there are questions that analysis of our database does not yet permit us to address such as the possibility of an effect on differences in cell cycle mechanisms (Dehay and Kennedy, 2007), or the effect of variability in the location of GABAergic proliferation when comparing rodents to humans (Letinic et al., 2002; Molnar and Cheung, 2006; Molyneaux et al., 2007). Such differences may be exemplified by a recent statistical analysis of the pulvinar (Chalfin et al., 2007), which in humans also has a dual source of neurogenesis (Letinic and Rakic, 2001). However, it is clear that the timing of neurogenesis alone is an important factor in development, given the evidence that timing might predict such properties as laminar position, electrophysiology responses, and neuronal morphology, including projection patterns (Caviness, 1982; Rakic, 1988; Takahashi et al., 1999; Lai et al., 2008). As datapoints are added to our database, 
Table 2 |The statistical model is used to produce estimates for postconception dates for GABAergic and subplate developmental neural events in humans.

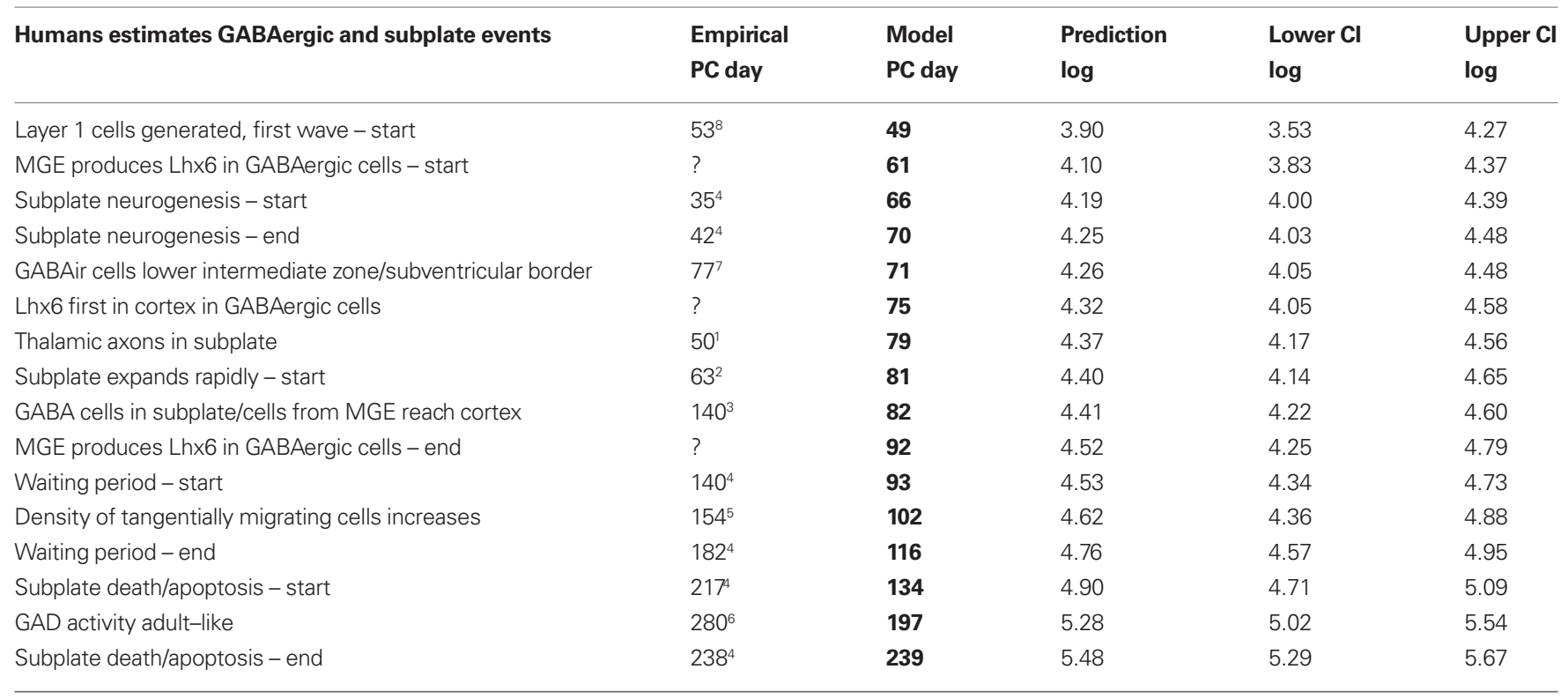

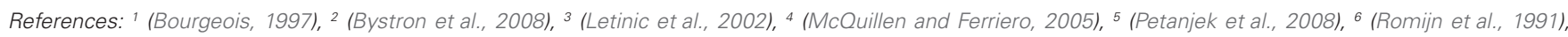
7 (Zecevic and Milosevic, 1997), 8 (Zecevic et al., 1999).

Abbreviations: MGE (medial ganglionic eminence); Lhx6 (LIM homeobox protein 6); GABA ( $\gamma$-aminobutyric acid); GABAir ( $\gamma$-aminobutyric acid immunoreactive); GAD (glutamic acid decarboxylase).

Tables 3 |The table below includes the neural events used in our statistical analysis, with GABAergic and subplate events indicated by an asterisk.

(A) Empirically derived and predicted mouse neural events in chronological order according to empirical dates, together with predictions and confidence limits on a log scale. Similar data are included for rats in (B), and macaques in (C). For comparative purposes these are listed in the same order as the mouse data.

\begin{tabular}{|c|c|c|c|c|c|}
\hline & $\begin{array}{l}\text { Empirical } \\
\text { PC days }\end{array}$ & $\begin{array}{l}\text { Prediction } \\
\text { PC days }\end{array}$ & $\begin{array}{l}\text { Prediction } \\
\text { log }\end{array}$ & $\begin{array}{l}\text { Lower CL } \\
\text { log }\end{array}$ & $\begin{array}{l}\text { Upper CL } \\
\text { log }\end{array}$ \\
\hline \multicolumn{6}{|l|}{ (A) MOUSE } \\
\hline Retinal ganglion cell generation - start & 10.5 & 9.4 & 2.24 & 2.08 & 2.40 \\
\hline Superficial SC laminae - start & 10.5 & 9.7 & 2.27 & 2.11 & 2.43 \\
\hline Neurogenesis cortical layer VI - start (VC) & 11.0 & 11.4 & 2.43 & 2.28 & 2.59 \\
\hline dLGN - peak & 12.0 & 11.8 & 2.47 & 2.31 & 2.63 \\
\hline Amygdala - peak & 12.0 & 11.6 & 2.45 & 2.30 & 2.61 \\
\hline Neurogenesis cortical layer $\mathrm{V}$ - start (VC) & 12.0 & 13.0 & 2.56 & 2.41 & 2.72 \\
\hline Subplate neurogenesis - end* & 12.0 & 12.6 & 2.53 & 2.37 & 2.69 \\
\hline Optic axons at chiasm of optic tract & 13.0 & 11.7 & 2.46 & 2.31 & 2.62 \\
\hline Superior colliculus - peak & 13.0 & 12.3 & 2.51 & 2.35 & 2.66 \\
\hline Retinal ganglion cells - peak & 13.0 & 12.7 & 2.54 & 2.39 & 2.70 \\
\hline Septal nuclei-peak & 13.0 & 12.4 & 2.51 & 2.36 & 2.67 \\
\hline Entorhinal cortex - peak & 13.0 & 12.6 & 2.54 & 2.38 & 2.69 \\
\hline Subiculum - peak & 13.0 & 13.2 & 2.58 & 2.42 & 2.74 \\
\hline Neurogenesis cortical layer $V$ - peak (VC) & 13.0 & 15.0 & 2.71 & 2.55 & 2.86 \\
\hline Neurogenesis cortical lamina VI - end (VC) & 13.0 & 14.4 & 2.67 & 2.51 & 2.83 \\
\hline
\end{tabular}


Tables 3 | (Continued)

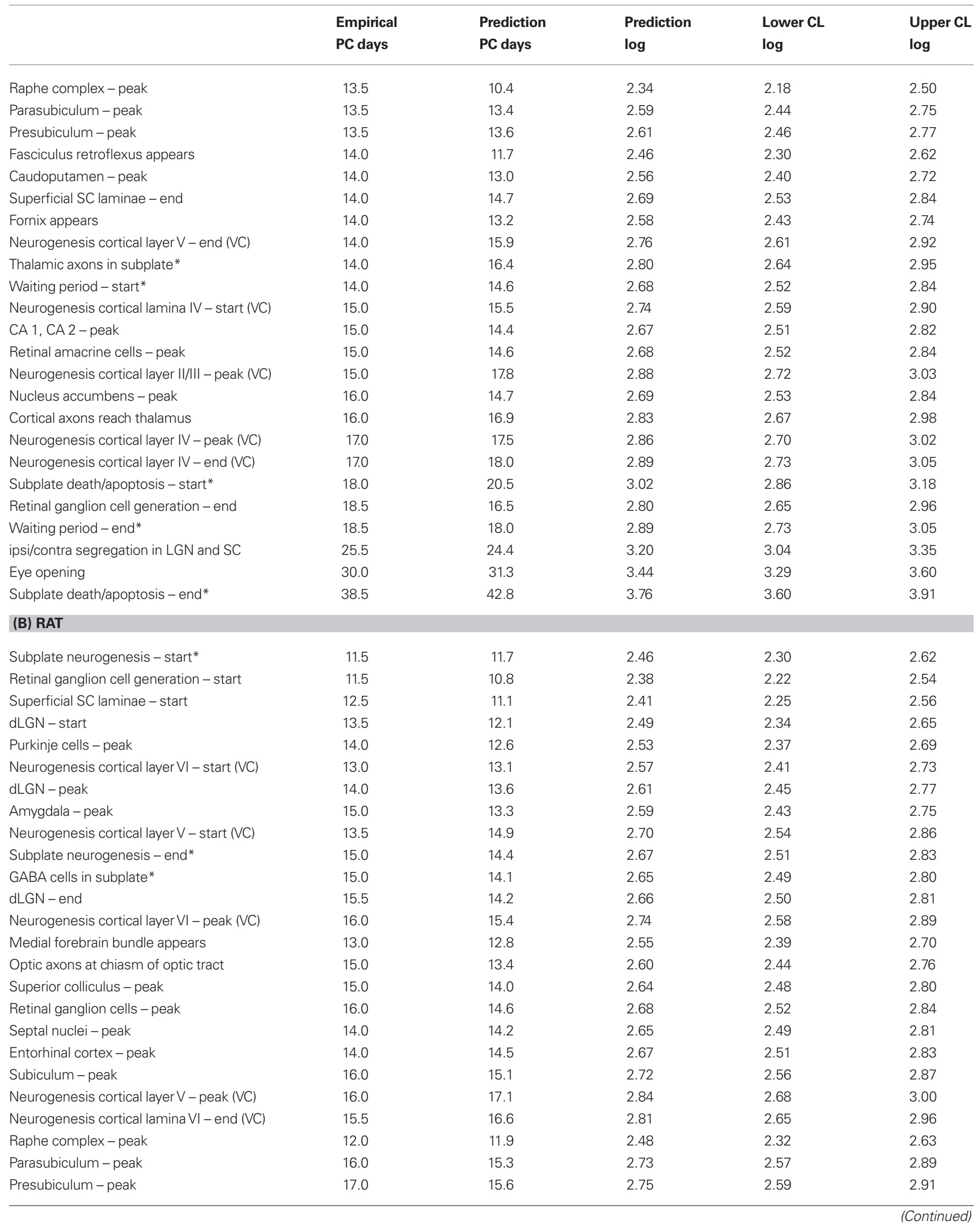


Tables 3 | (Continued)

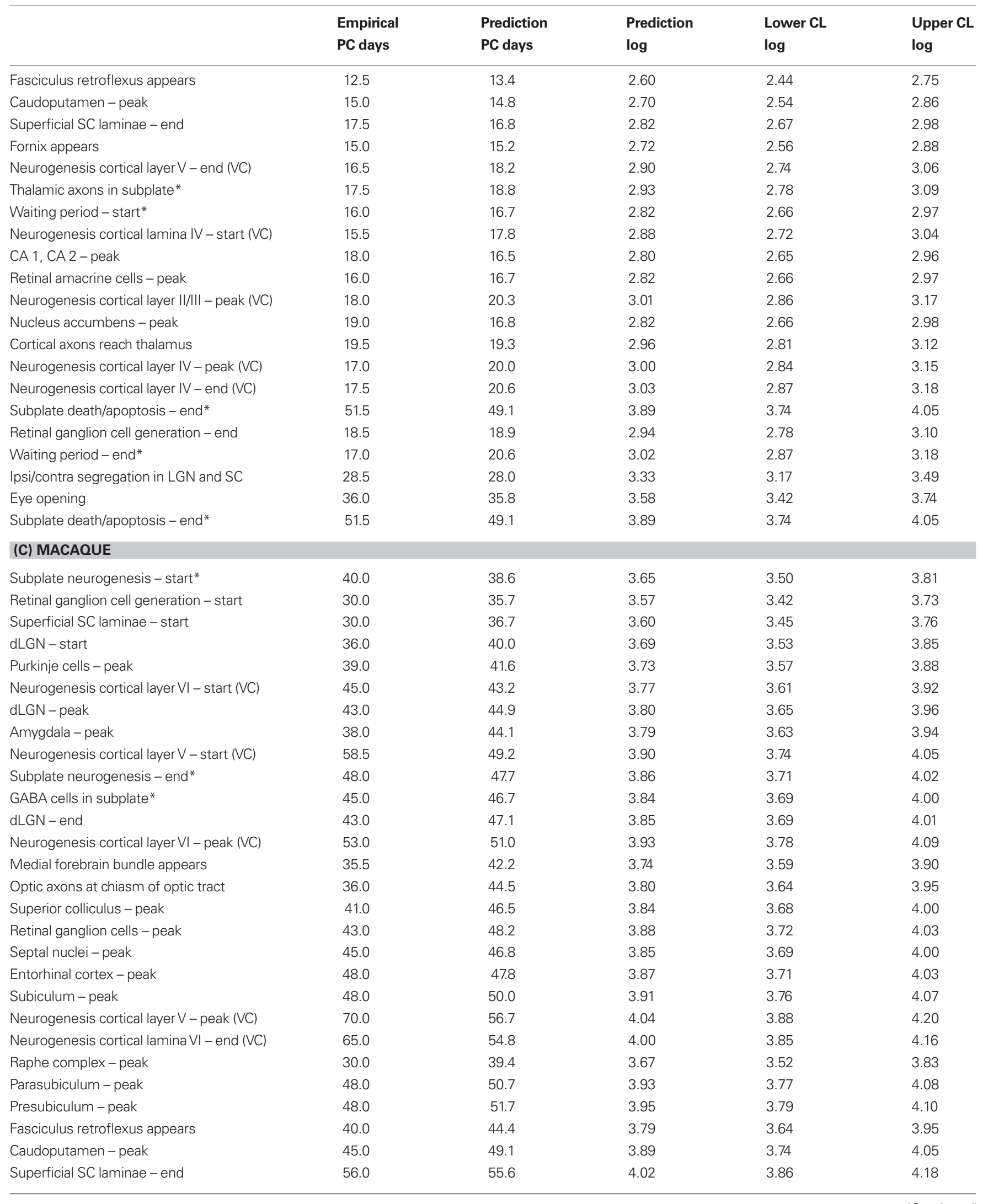




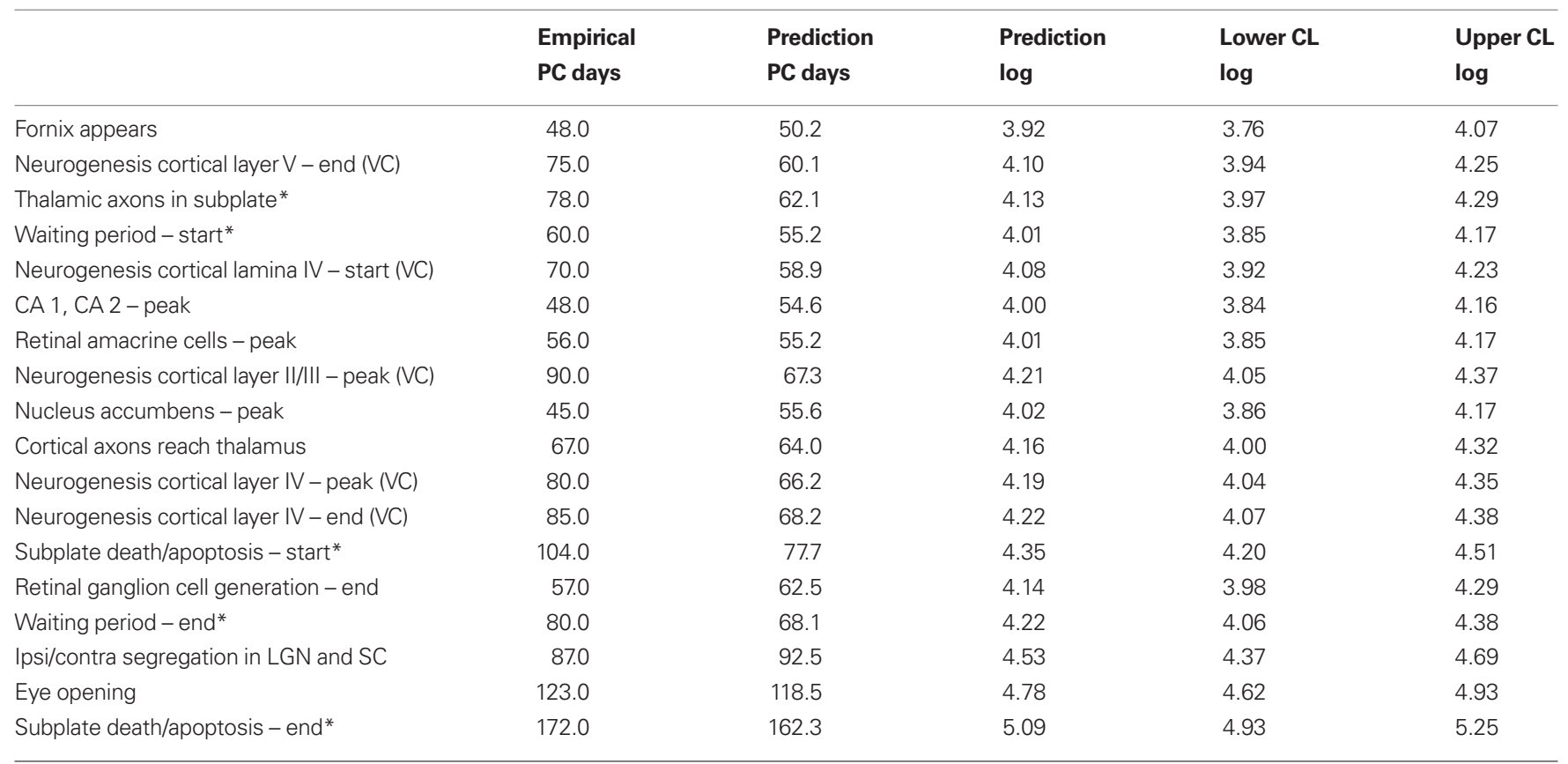

References for all data obtained from our database are available at www.translatingtime.net.

Abbreviations: SC (superior colliculus); dLGN (dorsal lateral geniculate nucleus); VC (visual cortex); CA (cornu ammonis).

we hope to test if a neuron's role is more closely related to the location of its birthplace, or the timing of its birth date.

One additional limitation we should point out arises because early PN days in rodent brain development correspond to in utero timing in humans. The result is that the effects of a perinatal wave of synaptogenesis (Zecevic and Rakic, 1991), the onslaught of experience surrounding birth, and the mother/offspring interaction are not included, as we have not yet identified data points associated with these events that fit into statistical models.

\section{REFERENCES}

Akbarian, S., Huntsman, M. M., Kim, J. J., Tafazzoli, A., Potkin, S. G., Bunney, W. E., Jr., and Jones, E. G. (1995). GABAA receptor subunit gene expression in human prefrontal cortex: comparison of schizophrenics and controls. Cereb. Cortex 5, 550-560.

Akbarian, S., Kim, J. J., Potkin, S. G., Hetrick, W. P., Bunney, W. E., Jr., and Jones, E. G. (1996). Maldistribution of interstitial neurons in prefrontal white matter of the brains of schizophrenic patients. Arch. Gen. Psychiatry 53, 425-436.

Anderson, S. A., Marin, O., Horn, C., Jennings, K., and Rubenstein, J. L. (2001). Distinct cortical migrations from the medial and lateral ganglionic eminences. Development 128, 353-363.

Ascoli, G. A., Alonso-Nanclares, L., Anderson, S. A., Barrionuevo, G.,
Benavides-Piccione, R., Burkhalter, A., Buzsaki, G., Cauli, B., Defelipe, J., Fairen, A., Feldmeyer, D., Fishell, G., Fregnac, Y., Freund, T. F., Gardner, D., Gardner, E. P., Goldberg, J. H., Helmstaedter,M.,Hestrin,S., Karube, F., Kisvarday, Z. F., Lambolez, B., Lewis, D. A., Marin, O., Markram, H., Munoz, A., Packer, A., Petersen, C. C., Rockland, K. S., Rossier, J., Rudy, B., Somogyi, P., Staiger, J. F., Tamas, G., Thomson, A. M., ToledoRodriguez, M., Wang, Y., West, D. C., and Yuste, R. (2008). Petilla terminology: nomenclature of features of, GABAergic interneurons of the cerebral cortex. Nat. Rev. 9, 557-568.

Bayer, L., Serafin, M., Eggermann, E., Saint-Mleux, B., Machard, D., Jones, B. E., and Muhlethaler,M. (2004). Exclusive postsynaptic action of hypocretin-orexin on sublayer $6 \mathrm{~b}$ cortical neurons. J. Neurosci. 24, 6760-6764.

\section{ACKNOWLEDGMENTS}

We thank James Hyde for assistance with figure production, Amanda James and Kristi Erbach for excellent technical assistance, and Richard Darlington for suggestions on the statistical analyses. This project was supported by NIH Grant Number P20 RR16460 from the IDeA Networks of Biomedical Research Excellence (INBRE) Program of the National Center for Research Resources and NSF Grant Number 0849627 to BC, and NSF Grant Number 0849684 to RN.

Behar, T. N., Li, Y. X., Tran, H. T., Ma, W., Dunlap, V., Scott, C., and Barker, J. L. (1996). GABA stimulates chemotaxis and chemokinesis of embryonic cortical neurons via calcum-dependent mechanisms. J. Neurosci. 16, 1808-1818.

Behar, T. N., Schaffner, A. E., Scott, C. A., O'Connell, C., and Barker, J. L. (1998). Differential response of cortical plate and ventricular zone cells to GABA as a migration stimulus. J. Neurosci. 18 , 6378-6387.

Ben-Ari, Y., Khalilov, I., Represa, A., and Gozlan, H. (2004). Interneurons set the tune of developing networks. Trends Neurosci. 27, 422-427.

Ben-Ari, Y., Khazipov, R., Leinekugel, X., Caillard, O., and Gaiarsa, J. L. (1997). GABAA, NMDA and AMPA receptors: a developmentally regulated 'menage a trois'. Trends Neurosci. 20, 523-529.

Bourgeois, J. P. (1997). Synaptogenesis, heterochrony and epigenesis in the mammalian neocortex. Acta Paediatr. 422, 27-33.

Bredt, D. S., and Snyder, S. H. (1992). Nitric oxide, a novel neuronal messenger. Neuron 8, 3-11.

Burkhalter, A. (2008). Many specialists for suppressing cortical excitation. Front. Neurosci. 2, 155-167. doi: 10.3389/neuro.01.026.2008

Butt, S. J., Cobos, I., Golden, J., Kessaris, N. Pachnis, V., and Anderson, S. (2007). Transcriptional regulation of cortical interneuron development. J. Neurosci. 27, 11847-11850.

Butt, S. J., Fuccillo, M., Nery, S., Noctor, S., Kriegstein, A., Corbin, J. G., and Fishell, G. (2005). The temporal and spatial origins of cortical interneurons predict their physiological subtype. Neuron 48, 591-604.

Bystron, I., Blakemore, C., and Rakic, P. (2008). Development of the human cerebral cortex: Boulder Committee 
revisited. Nat. Rev. Neurosci. 9, 110-122.

Cauller,L.J., Clancy, B., and Connors, B. W. (1998). Backward cortical projections to primary somatosensory cortex in rats extend long horizontal axons in layer I. J. Comp. Neurol. 390, 297-310.

Caviness, V. S., Jr. (1982). Early events of neocortical assembly: experimental studies and human pathology. Int. J. Neurol. 16-17, 102-109.

Chalfin, B. P., Cheung, D. T., Muniz, J. A., de Lima Silveira, L. C., and Finlay, B. L. (2007). Scaling of neuron number and volume of the pulvinar complex in New World primates: comparisons with humans, other primates, and mammals. J. Comp. Neurol. 504, 265-274.

Chang, A., Smith, M. C., Yin, X., Fox, R. J., Staugaitis, S. M., and Trapp, B. D. (2008). Neurogenesis in the chronic lesions of multiple sclerosis. Brain 131, 2366-2375.

Chun, J.J., Nakamura, M. J., and Shatz, C. J. (1987). Transient cells of the developing mammalian telencephalon are peptide-immunoreactive neurons. Nature 325, 617-620.

Chun, J. J., and Shatz, C. J. (1989a). The earliest-generated neurons of the cat cerebral cortex: characterization by MAP2 and neurotransmitter immunohistochemistry during fetal life. J. Neurosci. 9, 1648-1667.

Chun, J. J., and Shatz, C. J. (1989b). Interstitial cells of the adult neocortical white matter are the remnant of the early generated subplate neuron population. J. Comp. Neurol. 282, 555-569.

Clancy, B., and Cauller, L. J. (1999). Widespread projections from subgriseal neurons (layer VII) to layer I in adult rat cortex. J. Comp. Neurol. 407, 275-286.

Clancy, B., da Silva Filho, M., Hester, F., and Friedlander, M. J. (1997). Structure, function and connectivity of white matter neurons in mammalian visual cortex. Abstr. - Soc. Neurosci. 23, 1268 .

Clancy, B., Darlington, R. B., and Finlay, B. L. (2000). The course of human events: predicting the timing of primate neural development. Dev. Sci. 3, 57-66.

Clancy, B., Darlington, R. B., and Finlay, B. L. (2001a). Translating developmental time across mammalian species. Neuroscience 105, 7-17.

Clancy, B., Silva-Filho, M., and Friedlander, M. J. (2001b). Structure and projections of white matter neurons in the postnatal rat visual cortex. J. Comp. Neurol. 434, 233-252.

Clancy, B., Finlay, B. L., Darlington, R. B., and Anand, K.J.(2007a). Extrapolating brain development from experimental species to humans. Neurotoxicology 28 , 931-937.

Clancy, B., Kersh, B., Hyde, J., Darlington, R. B., Anand, K. J., and Finlay, B. L. (2007b). Web-based method for translating neurodevelopment from laboratory species to humans. Neuroinformatics 5, 79-94.

Cobas, A., Fairen, A., Alvarez-Bolado, G., and Sanchez, M. P. (1991). Prenatal development of the intrinsic neurons of the rat neocortex: a comparative study of the distribution of GABA-immunoreactive cells and the GABAA receptor. Neuroscience 40, 375-397.

Colombo, J. A., and Bentham, C. (2006). Immunohistochemical analysis of subcortical white matter astroglia of infant and adult primate brains, with a note on resident neurons. Brain Res. 1100, 93-103.

Cronbach, L. J., and Meehl, P. E. (1955). Construct validity in psychological tests. Psychol. Bull. 52, 281-302.

Dammann, O., Kuban, K. C., and Leviton, A. (2002). Perinatal infection, fetal inflammatory response, white matter damage, and cognitive limitations in children born preterm. Ment. Retard. Dev. Disabil. Res. Rev. 8, 46-50.

Darlington, R. B. (1990). Regression and Linear Models. New York, McGraw-Hill.

De Carlos, J. A., and O'Leary, D. D. (1992). Growth and targeting of subplate axons and establishment of major cortical pathways. J. Neurosci. 12, 1194-1211.

de Graaf-Peters, V. B., and HaddersAlgra, M. (2006). Ontogeny of the human central nervous system: what is happening when? Early Hum. Dev. 82, 257-266.

DeDiego, I., Smith-Fernandez, A., and Fairen, A. (1994). Cortical cells that migrate beyond area boundaries: characterization of an early neuronal population in the lower intermediate zone of prenatal rats. Eur. J. Neurosci. 6, 983-997.

Dehay, C., and Kennedy, H. (2007). Cellcycle control and cortical development. Nat. Rev. 8, 438-450.

Del Rio, J. A., Martinez, A., Auladell, C., and Soriano, E.(2000). Developmental history of the subplate and developing white matter in the murine neocortex. Neuronal organization and relationship with the main afferent systems at embryonic and perinatal stages. Cereb. Cortex 10, 784-801.

Eastwood, S. L., and Harrison, P. J. (2006). Cellular basis of reduced cortical reelin expression in schizophrenia. Am. J. Psychiatry 163, 540-542.
Esclapez, M., Campistron, G., and Trottier, S. (1987). Immunocytochemical localization and morphology of GABA-containing neurons in the prefrontal and frontoparietal cortex of the rat. Neurosci. Lett. 77, 131-136.

Fabri, M., and Manzoni, T. (1996). Glutamate decarboxylase immunoreactivity in corticocortical projecting neurons of rat somatic sensory cortex. Neuroscience 72, 435-448.

Fabri, M., and Manzoni, T. (2004). Glutamic acid decarboxylase immunoreactivity in callosal projecting neurons of cat and rat somatic sensory areas. Neuroscience 123, 557-566.

Finlay, B. L., and Darlington, R. B. (1995). Linked regularities in the development and evolution of mammalian brains. Science 268, 1578-1584.

Finlay, B. L., Darlington, R. B., and Nicastro, N. (2001). Developmental structure in brain evolution. Behav. Brain Sci. 24, 263-278; discussion 278-308.

Finlay, B. L., Hersman, M. N., and Darlington, R. B. (1998). Patterns of vertebrate neurogenesis and the paths of vertebrate evolution. Brain Behav. Evol. 52, 232-242.

Freund, T. F., and Katona, I. (2007). Perisomatic inhibition. Neuron 56, 33-42.

Friauf, E., McConnell, S. K., and Shatz, C. J. (1990). Functional synaptic circuits in the subplate during fetal and early postnatal development of cat visual cortex. J. Neurosci. 10, 2601-2613.

Friedlander, M. J. (2008). Lifespan longitudinal multitasking by cortical neurons. Future Neurol. 3, 117-123.

Friedlander, M. J., and TorresReveron, J. (2009). The changing roles of neurons in the cortical subplate. Front Neuroanat. 3, 15. doi: 10.3389/neuro.05.015.2009

Gao, W. J., Newman, D. E. Wormington, A. B., and Pallas, S. L. (1999). Development of inhibitory circuitry in visual and auditory cortex of postnatal ferrets: immunocytochemical localization of GABAergic neurons. J. Comp. Neurol. 409, 261-273.

Garbossa, D., Fontanella, M., Tomasi, S., Ducati, A., and Vercelli, A. (2004). Differential distribution of NADPHdiaphorase histochemistry in human cerebral cortex. Brain Res. 1034, $1-10$.

Ghosh, A., Antonini, A., McConnell, S. K., and Shatz, C. J. (1990). Requirement for subplate neurons in the formation of thalamocortical connections. Nature 347, 179-181.

Gilmore, E. C., and Herrup, K. (2001) Neocortical cell migration: GABAergic neurons and cells in layers I and VI move in a cyclin-dependent kinase 5independent manner. J. Neurosci. 21, 9690-9700.

Goffinet, A., and Rakic, P. (2000). Mouse Brain Development. Berlin, NY, Springer.

Gomez-Pinilla, F., and Cotman, C. W. (1992). Transient lesion-induced increase of basic fibroblast growth factor and its receptor in layer VIb (subplate cells) of the adult rat cerebral cortex. Neuroscience 49, 771-780.

Gonchar, Y. A., Johnson, P. B., and Weinberg, R. J. (1995). GABA-immunopositive neurons in rat neocortex with contralateral projections to S-I. Brain Res. 697, 27-34.

Hanganu,I.L., Kilb, W., and Luhmann, H. J. (2001).Spontaneous synaptic activity of subplate neurons in neonatal rat somatosensory cortex. Cereb. Cortex 11, 400-410.

Hanganu, I. L., Kilb, W., and Luhmann, H. J. (2002). Functional synaptic projections onto subplate neurons in neonatal rat somatosensory cortex. J. Neurosci. 22, 7165-7176.

Hendry, S. H., Houser, C. R., Jones, E. G., and Vaughn, J. E. (1983). Synaptic organization of immunocytochemically identified GABA neurons in the monkey sensory-motor cortex. J. Neurocytol. 12, 639-660.

Hendry, S. H., and Jones, E. G. (1991). GABA neuronal subpopulations in cat primary auditory cortex: colocalization with calcium binding proteins. Brain Res. 543, 45-55.

Hendry, S. H., Schwark, H. D., Jones, E. G., and Yan, J. (1987). Numbers and proportions of GABA-immunoreactive neurons in different areas of monkey cerebral cortex. J. Neurosci. 7, 1503-1519.

Heuer, H., Christ, S., Friedrichsen, S., Brauer, D., Winckler, M., Bauer, K., and Raivich, G. (2003). Connective tissue growth factor: a novel marker of layer VII neurons in the rat cerebral cortex. Neuroscience 119, 43-52.

Higo, S., Udaka, N., and Tamamaki, N. (2007). Long-range GABAergic projection neurons in the cat neocortex. $J$. Comp. Neurol. 503, 421-431.

Hogan, D., and Berman, N. E. (1992). The development of neuropeptide $\mathrm{Y}$ immunoreactive neurons in cat visual cortical areas. Brain Res. Dev. Brain Res. 67, 343-369.

Huntley, G. W., Hendry, S. H., Killackey, H. P., Chalupa, L. M., and Jones, E. G. (1988). Temporal sequence of neurotransmitter expression by developing neurons of fetal monkey visual cortex. Brain Res. 471 69-96. 
Jensen, A., Vaihinger, H. M., and Meier, C. (2003). [Perinatal brain damage--from neuroprotection to neuroregeneration using cord blood stem cells]. Med. Klin. (Munich) 98(Suppl. 2), 22-26.

Kanold, P. O. (2004). Transient microcircuits formed by subplate neurons and their role in functional development of thalamocortical connections. Neuroreport 15, 2149-2153.

Kanold, P. O., Kara, P., Reid, R. C., and Shatz, C. J. (2003). Role of subplate neurons in functional maturation of visual cortical columns. Science 301, 521-525.

Kanold, P. O., and Shatz, C. J. (2006). Subplate neurons regulate maturation of cortical inhibition and outcome of ocular dominance plasticity. Neuron 51, 627-638.

Kirkpatrick, B., Conley, R. C., Kakoyannis, A., Reep, R. L., and Roberts, R. C. (1999). Interstitial cells of the white matter in the inferior parietal cortex in schizophrenia: an unbiased cell-counting study. Synapse 34, 95-102.

Kostovic, I., and Judas, M. (2006). Prolonged coexistence of transient and permanent circuitry elements in the developing cerebral cortex of fetuses and preterm infants. Dev. Med. Child Neurol. 48, 388-393.

Kostovic, I., and Rakic, P. (1980). Cytology and time of origin of interstitial neurons in the white matter in infant and adult human and monkey telencephalon. J. Neurocytol. 9, 219-242.

Kostovic, I., and Rakic, P. (1990). Developmental history of the transient subplate zone in the visual and somatosensory cortex of the macaque monkey and human brain. J. Comp. Neurol. 297, 441-470.

Kristt, D. A. (1979). Development of neocortical circuitry: histochemical localization of acetylcholinesterase in relation to the cell layers of rat somatosensory cortex. J. Comp. Neurol. 186, 1-15.

Lai, T., Jabaudon, D., Molyneaux, B. J., Azim, E., Arlotta, P., Menezes, J. R., and Macklis, J. D. (2008). SOX5 controls the sequential generation of distinct corticofugal neuron subtypes. Neuron $57,232-247$.

Lauder, J. M., Han, V. K., Henderson, P., Verdoorn, T., and Towle, A. C. (1986). Prenatal ontogeny of the GABAergic system in the rat brain: an immunocytochemical study. Neuroscience 19, 465-493.

Lavdas, A. A., Grigoriou, M., Pachnis, V., and Parnavelas, J. G. (1999). The medial ganglionic eminence gives rise to a population of early neurons in the developing cerebral cortex. J. Neurosci. 19, 7881-7888.
Lazar, N.L., Rajakumar,N., and Cain, D. P. (2008). Injections of NGF into neonatal frontal cortex decrease social interaction as adults: a rat model of schizophrenia. Schizophr. Bull. 34, 127-136.

Lein, E. S., Finney, E. M., McQuillen, P. S. and Shatz, C. J. (1999). Subplate neuron ablation alters neurotrophin expression and ocular dominance column formation. Proc. Natl. Acad. Sci. U. S. A. 96, 13491-13495.

Letinic, K., and Rakic, P. (2001). Telencephalic origin of human thalamic GABAergic neurons. Nat. Neurosci. 4, 931-936.

Letinic, K.,Zoncu, R., and Rakic, P. (2002). Origin of GABAergic neurons in the human neocortex. Nature 417 , 645-649.

Leviton, A., and Gressens, P. (2007). Neuronal damage accompanies perinatal white-matter damage. Trends Neurosci. 30, 473-478.

Levitt,P. (2005).Disruption of interneuron development. Epilepsia 46(Suppl. 7), 22-28.

Lewis, D. A., Hashimoto, T., and Volk, D. W. (2005). Cortical inhibitory neurons and schizophrenia. Nat. Rev. 6, 312-324.

Luhmann, H. J., Reiprich, R. A., Hanganu, I., and Kilb, W. (2000). Cellular physiology of the neonatal rat cerebral cortex: intrinsic membrane properties, sodium and calcium currents. J. Neurosci. Res. 62, 574-584.

Luskin, M. B., Pearlman, A. L., and Sanes, J. R. (1988). Cell lineage in the cerebral cortex of the mouse studied in vivo and in vitro with a recombinant retrovirus. Neuron 1, 635-647.

Maric, D., Liu, Q. Y., Maric, I., Chaudry, S., Chang, Y. H., Smith, S. V., Sieghart, W., Fritschy, J. M., and Barker, J. L. (2001). GABA expression dominates neuronal lineage progression in the embryonic rat neocortex and facilitates neurite outgrowth via GABA(A) autoreceptor/Cl-channels. J. Neurosci. 21, 2343-2360.

Marin, O., and Rubenstein, J. L. (2001). A long, remarkable journey: tangential migration in the telencephalon. Nat. Rev. 2, 780-790.

Marin-Padilla, M. (1978). Dual origin of the mammalian neocortex and evolution of the cortical plate. Anat. Embryol. 152, 109-126.

Marín-Padilla, M. (1988). Early ontogenesis of the human cerebral cortex. In Cerebral Cortex, Vol. VII, Development and Maturation of the Cerebral Cortex, A. Peters, and E. G. Jones, eds, (New York, Plenum), pp. 1-30.

Marin-Padilla, M., and MarinPadilla, T. M. (1982). Origin, prenatal development and structural organization of layer I of the human cerebral (motor) cortex. A Golgi study. Anat. Embryol. 164, 161-206.

McConnell,S.K., Ghosh,A., and Shatz, C. J. (1989). Subplate neurons pioneer the first axon pathway from the cerebral cortex. Science 245, 978-982.

McDonald, C. T., and Burkhalter, A. (1993). Organization of long-range inhibitory connections with rat visual cortex. J. Neurosci. 13, 768-781.

McQuillen, P. S., and Ferriero, D. M. (2005). Perinatal subplate neuron injury: implications for cortical development and plasticity. Brain Pathol. $15,250-260$.

Meinecke, D. L., and Peters, A. (1987). GABA immunoreactive neurons in rat visual cortex. J. Comp. Neurol. 261, 388-404.

Metin, C., Vallee, R. B., Rakic, P., and Bhide, P. G. (2008). Modes and mishaps of neuronal migration in the mammalian brain. J. Neurosci. 28 11746-11752.

Meyer,G.,Soria,J.M.,Martinez-Galan, J. R. Martin-Clemente, B., and Fairen, A. (1998). Different origins and developmental histories of transient neurons in the marginal zone of the fetal and neonatal rat cortex. J. Comp. Neurol. 397, 493-518.

Miyoshi, G., Bessho, Y., Yamada, S., and Kageyama, R. (2004). Identification of a novel basic helix-loop-helix gene, Heslike, and its role in GABAergic neurogenesis. J. Neurosci. 24, 3672-3682.

Miyoshi, G., Butt, S. J., Takebayashi, H. and Fishell, G. (2007). Physiologically distinct temporal cohorts of cortical interneurons arise from telencephalic Olig2-expressing precursors. J. Neurosci. 27, 7786-7798.

Molnar, Z., and Cheung, A. F. (2006). Towards the classification of subpopulations of layer $V$ pyramidal projection neurons. Neurosci. Res. 55, 105-115.

Molyneaux, B. J., Arlotta, P., Menezes, J. R., and Macklis, J. D. (2007). Neuronal subtype specification in the cerebral cortex. Nat. Rev. 8, 427-437.

Nagarajan, R., and Clancy, B. (2008). Phylogenetic proximity revealed by neurodevelopmental event timings. Neuroinformatics 6, 71-79.

Nie, F., and Wong-Riley, M. T. (1996). Metabolic and neurochemical plasticity of gamma-aminobutyric acidimmunoreactive neurons in the adult macaque striate cortex following monocular impulse blockade: quantitative electron microscopic analysis. J. Comp. Neurol. 370, 350-366.

Owens, D. F., and Kriegstein, A. R. (2002). Is there more to GABA than synaptic inhibition? Nat. Rev. 3, 715-727.
Peduzzi, J. D. (1988). Genesis of GABAimmunoreactive neurons in the ferret visual cortex. J. Neurosci. 8, 920-931.

Petanjek, Z., Berger, B., and Esclapez, M. (2009). Origins of cortical GABAergic neurons in the cynomolgus monkey. Cereb. Cortex 19, 249-262.

Petanjek, Z., Dujmovic, A., Kostovic, I. and Esclapez, M. (2008). Distinct origin of GABA-ergic neurons in forebrain of man, nonhuman primates and lower mammals. Coll. Antropol. 32(Suppl. 1), 9-17.

Pinon, M. C., Jethwa, A., Jacobs, E., Campagnoni, A., and Molnar, Z. (2009). Dynamic integration of subplate neurons into the cortical barrel field circuitry during postnatal development in the Golli-tau-eGFP (GTE) mouse. J. Physiol. 587, 1903-1915.

Pinto, A., Fuentes, C., and Pare, D. (2006). Feedforward inhibition regulates perirhinal transmission of neocortical inputs to the entorhinal cortex: ultrastructural study in guinea pigs. J. Comp. Neurol. 495, 722-734.

Price, D. J., Aslam, S., Tasker, L., and Gillies, K. (1997). Fates of the earliest generated cells in the developing murine neocortex. J. Comp. Neurol. 377, 414-422.

Princivalle, A., Regondi, M. C., Frassoni, C., Bowery, N. G., and Spreafico, R. (2000). Distribution of GABA(B) receptor protein in somatosensory cortex and thalamus of adult rats and during postnatal development. Brain Res. Bull. 52, 397-405.

Rakic, P. (1988). Specification of cerebral cortical areas. Science 241, 170-176.

Rakic, P. (2003). Developmental and evolutionary adaptations of cortical radial glia. Cereb. Cortex 13, 541-549.

Rakic, P. (2006). A century of progress in corticoneurogenesis: from silver impregnation to genetic engineering. Cereb. Cortex 16(Suppl. 1), i3-i17.

Reep, R. L. (2000). Cortical layer VII and persistent subplate cells in mammalian brains. Brain Behav. Evol. 56, 212-234.

Reep, R. L., and Goodwin, G. S. (1988). Layer VII of rodent cerebral cortex. Neurosci. Lett. 90, 15-20.

Robertson, R. T., Annis, C. M., Baratta, J., Haraldson, S., Ingeman, J., Kageyama, G. H., Kimm, E., and Yu, J. (2000). Do subplate neurons comprise a transient population of cells in developing neocortex of rats? J. Comp. Neurol. 426, 632-650.

Robinson, S., Petelenz, K., Li, Q., Cohen, M. L., Dechant, A., Tabrizi, N., Bucek, M., Lust, D., and Miller, R. H. (2005). Developmental changes induced by graded prenatal systemic hypoxic-ischemic insults in rats. Neurobiol. Dis. 18, 568-581. 
Robinson, S., Qing, L., DeChant, A., and Cohen, M. L. (2006). Neonatal loss of gamma-aminobutyric acid pathway expression after human perinatal brain injury. J. Neurosurg.104, 396-408.

Romijn, H. J., Hofman, M. A., and Gramsbergen, A. (1991). At what age is the developing cerebral cortex of the rat comparable to that of the full-term newborn human baby? Early Hum. Dev. 26, 61-67.

Schiffmann, S., Campistron, G., Tugendhaft, P., Brotchi, J., Flament-Durand, J., Geffard, M., and Vanderhaeghen, J. J. (1988). Immunocytochemical detection of GABAergic nerve cells in the human temporal cortex using a direct gammaaminobutyric acid antiserum. Brain Res. 442, 270-278.

Silberberg, G., and Markram, H. (2007). Disynaptic inhibition between neocortical pyramidal cells mediated by Martinotti cells. Neuron 53, 735-746.

Smart, I. H., Dehay, C., Giroud, P., Berland, M., and Kennedy, H. (2002). Unique morphological features of the proliferative zones and postmitotic compartments of the neural epithelium giving rise to striate and extrastriate cortex in the monkey. Cereb. Cortex 12, 37-53.

Somogyi, P., Cowey, A., Halasz, N., and Freund, T. F. (1981). Vertical organization of neurones accumulating $3 \mathrm{H}-\mathrm{GABA}$ in visual cortex of rhesus monkey. Nature 294, 761-763.

Somogyi, P., Hodgson, A. J., Smith, A. D., Nunzi, M. G., Gorio, A., and Wu, J. Y. (1984). Different populations of GABAergic neurons in the visual cortex and hippocampus of cat contain somatostatin- or cholecystokininimmunoreactive material. J. Neurosci. 4, 2590-2603.

Suarez-Sola, M. L., GonzalezDelgado, F. J., Pueyo-Morlans, M., Medina-Bolivar, O. C., HernandezAcosta, N. C., Gonzalez-Gomez, M., and Meyer, G. (2009). Neurons in the white matter of the adult human neocortex. Front. Neuroanat. 3, 7. doi: 10.3389/neuro.05.007.2009

Sur, M., and Rubenstein, J. L. (2005). Patterning and plasticity of the cerebral cortex. Science 310, 805-810.

Takahashi, T., Goto, T., Miyama, S., Nowakowski, R. S., and Caviness, V. S., Jr. (1999). Sequence of neuron origin and neocortical laminar fate: relation to cell cycle of origin in the developing murine cerebral wall. J. Neurosci. 19, 10357-10371.

Tamamaki, N., Fujimori, K. E., and Takauji, R. (1997). Origin and route of tangentially migrating neurons in the developing neocortical intermediate zone. J. Neurosci. 17, 8313-8323.

Tao, Z., Van Gool, D., Lammens, M., and Dom, R. (1999). NADPH-diaphorasecontaining neurons in cortex, subcortical white matter and neostriatum are selectively spared in Alzheimer's disease. Dement. Geriatr. Cogn. Disord. 10, 460-468.

Teague-Ross, T. J., Lantz, S. M., Davis, C., James, A. L., Oonthonpan, L., Hyde, J., Bratton, G. N., and Clancy, B. (2008). Rat cortical subplate comparisons across development and aging. Society for Neuroscience Conference Abstract. 232, 14.

Tomioka, R., Okamoto, K., Furuta, T., Fujiyama, F., Iwasato, T., Yanagawa, Y., Obata, K., Kaneko, T., and Tamamaki, N. (2005). Demonstration of long-range GABAergic connections distributed throughout the mouse neocortex. Eur. J. Neurosci. 21, 1587-1600.

Tomioka, R., and Rockland, K. S. (2007). Long-distance corticocortical GABAergic neurons in the adult monkey white and gray matter. J. Comp. Neurol. 505, 526-538.

Torres-Reveron, J., and Friedlander, M. J. (2007). Properties of persistent postnatal cortical subplate neurons. $J$. Neurosci. 27, 9962-9974.
Ulfig, N. (2002). Ganglionic eminence of the human fetal brain - new vistas. Anat. Rec. 267, 191-195.

Valverde, F., Lopez-Mascaraque, L., Santacana, M., and De Carlos, J. A. (1995). Persistence of early-generated neurons in the rodent subplate: assessment of cell death in neocortex during the early postnatal period. J. Neurosci. 15, 5014-5024.

Van Eden, C. G., Mrzljak, L., Voorn, P., and Uylings, H. B. (1989). Prenatal development of GABA-ergic neurons in the neocortex of the rat. J. Comp. Neurol. 289, 213-227.

Voigt, T., Opitz, T., and de Lima, A. D. (2001). Synchronous oscillatory activity in immature cortical network is driven by GABAergic preplate neurons. J. Neurosci. 21, 8895-8905.

Wang, D. D., and Kriegstein, A. R. (2009). Defining the role of GABA in cortical development. J. Physiol. 587, 1873-1879.

Watakabe, A., Komatsu, Y., Nawa, H., and Yamamori, T. (2006). Gene expression profiling of primate neocortex: molecular neuroanatomy of cortical areas. Genes Brain Behav. 5(Suppl. 1), 38-43.

Watts, D. J., and Strogatz, S. H. (1998). Collective dynamics of 'small-world' networks. Nature 393, 440-442.

Winer, J. A., Larue, D. T. (1989). Populations of GABAergic neurons and axons in layer I of rat auditory cortex. Neuroscience 33, 499-515.

Woo, T. U., Beale, J. M., and Finlay, B. L. (1991). Dual fate of subplate neurons in a rodent. Cereb. Cortex 1, 433-443.

Woo, T. U., and Finlay, B. L. (1996). Cortical target depletion and ingrowth of geniculocortical axons: implications for cortical specification. Cereb. Cortex 6, 457-469.

Woo, T. U., Walsh, J. P., and Benes, F. M. (2004). Density of glutamic acid decarboxylase 67 messenger RNA-containing neurons that express the N-methyl-Daspartate receptor subunit NR2A in the anterior cingulate cortex in schizophrenia and bipolar disorder. Arch. Gen. Psychiatry 61, 649-657.

Yan, X. X., Garey, L. J., and Jen, L. S. (1996). Prenatal development of NADPH-diaphorase-reactive neurons in human frontal cortex. Cereb. Cortex 6, 737-745.

Yuste, R. (2005). Origin and classification of neocortical interneurons. Neuron 48, 524-527.

Zecevic, N., and Milosevic, A. (1997). Initial development of gamma-aminobutyric acid immunoreactivity in the human cerebral cortex. J. Comp. Neurol. 380, 495-506.

Zecevic, N., Milosevic, A., Rakic, S. and Marin-Padilla, M. (1999). Early development and composition of the human primordial plexiform layer: an immunohistochemical study. J. Comp. Neurol. 412, 241-254.

Zecevic, N., and Rakic, P. (1991). Synaptogenesis in monkey somatosensory cortex. Cereb. Cortex 1, 510-523.

Conflict of Interest Statement: The authors declare that the research was conducted in the absence of any commercial or financial relationships that could be construed as a potential conflict of interest.

Received: 03 July 2009; paper pending published:24 July 2009; accepted:04 September 2009; published online: 06 October 2009. Citation: Clancy B, Teague-Ross TJ and Nagarajan R (2009) Cross-species analyses of the cortical GABAergic and subplate neural populations. Front. Neuroanat. 3:20. doi: 10.3389/neuro.05.020.2009 Copyright (c) 2009 Clancy, Teague-Ross and Nagarajan. This is an open-access article subject to an exclusive license agreement between the authors and the Frontiers Research Foundation, which permits unrestricted use, distribution, and reproduction in any medium, provided the original authors and source are credited. 